\title{
PELATIHAN “E-LEARNING FROM HOME” BAGI GURU PENDIDIKAN ANAK USIA DINI PADA MASA PANDEMIC COVID19
}

\author{
Chandra Asri Windarsih ${ }^{1}$, Suhud Aryana ${ }^{2}$, Ammy Ramdhania ${ }^{3}$ \\ 1,2IKIP Siliwangi, Bandung, Indonesia \\ ${ }^{3}$ Cerah Eco School, Cimahi, Indonesia \\ *Penulis Koresponsensi, email: chandra-asri@ikipsiliwangi.ac.id
}

\begin{abstract}
The covid 19 pandemic outbreak continues to occur in various parts of the world including our country so that we immediately conduct a period of adaptation of new habits on all fronts, including the field of PAUD education, so that learning is all done at home. Learning From Home is carried out by parents, but curriculum, planning and assessment are still provided from the school. The purpose of the training is to know the steps that are used as guidelines in Learning From Home for teachers in the event of a pandemic, provide enlightenment and how to apply this method of devotion participatory approach with oriented teacher participation. The first step of the research is to analyze the situation, identification, objectives, problem solving plan, approach, implementation of training and evaluation. As a result of E-Learning From Home, teachers get new insights and enlightenment, teacher skills increase, media in demand in the form of quota-efficient applications, easy to use, accessible on mobile phones, and do not require a large memory. This devotion will be followed up with the dedication of simple animation making in defense for early childhood
\end{abstract}

\section{Keywords : Learning From Home, Teachers, Pandemic}

\begin{abstract}
Abstrak. Wabah pandemi covid 19 masih terus terjadi di berbagai belahan dunia termasuk negara kita sehingga kita segera melakukan masa adaptasi kebiasaan baru disemua lini, tidak terkecuali bidang pendidikan PAUD, sehingga pembelajaran semua dilakukan dirumah. Learning From Home ini dilaksanakan oleh orang tua, namun kurikulum, perencanaan dan penilaian tetap diberikan dari sekolah. Tujuan dari pelatihan adalah untuk mengetahui langkah-langkah yang dijadikan pedoman dalam Learning From Home bagi guru ketika terjadi pandemi, memberikan pencerahan dan bagaimana menerapkannya Metode yang dipakai Pengabdian ini pendekatan partisipatif dengan berorientasi pada keikutsertaan guru. Langkah awal penelitian melakukan analisis situasi, identifikasi maslah, tujuan, rencana pemecahan masalah, pendekatan, pelaksanaan pelatihan dan evaluasi. Hasil dari pengabdian E-Learning From Home guru mendapatkan wawasan baru dan pencerahan, kemampuan guru meningkat, media yang diminati berupa aplikasi yang hemat quota, mudah penggunaannya, dapat diakses di handphone, dan tidak membutuhkan memori yang besar. Pengabdian ini akan ditindak lanjuti dengan pengabdian pembuatan animasi sederhana dalam pembelajaran untuk anak usia dini.
\end{abstract}

Kata Kunci : Learning From Home, Guru, Pandemi

How to Cite: Windarsih, C. A., Aryana, S. ., \& Ramdhania, A. (2021). PELATIHAN “E-LEARNING FROM HOME” BAGI GURU PENDIDIKAN ANAK USIA DINI PADA MASA PANDEMIC COVID19. Mitra Mahajana: Jurnal Pengabdian Masyarakat, 2(1), 64-73. https://doi.org/10.37478/mahajana.v2i1.798

\section{PENDAHULUAN}

Pandemic COVID 19 dinyatakan sebagai wabah yang melanda negara kita sejak Maret 2020 memberikan dampak yang luar biasa pada berbagai sektor kehidupan masyarakat. Pendidikan yang menjadi determinan masa depan bangsa, ikut terimbas karena adanya kebijakan untuk memutus mata rantai penyebaran virus wabah itu melalui social distancing. Pelaksanaan kegiatan belajar dan mengajar secara tatap muka di seluruh lembaga pendidikan sementara dihentikan sampai batas waktu yang belum dapat dipastikan. Namun dalam rangka mencetak generasi bangsa yang unggul dan berkualitas, pendidikan tak boleh berhenti. Berbagai kebijakan segera dilakukan agar proses belajar mengajar dapat terus berlangsung dengan kondisi lingkungan yang disesuaikan. Wabah ini dapat dihindari penularannya dengan tindakan proaktif (Ashcroft et al., 2020). Topik ini dipilih karena masih banyak guru yang belum siap ketika terjadi wabah dan pasca pandemi, belum semua guru mampu secara mandiri mengembangkan e-learning from home pada saat masa adaptasi kebiasaan baru. 
Demikian halnya dengan penyelenggaraan pendidikan anak usia dini (Armiyati et al., 2019) bahwa penyelenggaraan proses pembelajaran harus interaktif, menyenangkan, menantang, dan dapat memotivasi anak didik. Dengan demikian anak didik mendapat ruang gerak yang cukup untuk berkreasi dan mengembangkan kemandirian sesuai bakat dan minatnya, tanpa mengabaikan perkembangan fisik dan psikologis anak didik. Untuk memudahkan berlangsungnya proses pembelajaran, guru PAUD berupaya menyusunnya dalam bentuk perencanaan pembelajaran sebagai panduan (Sufiati \& Afifah, 2019) Perencanaan pembelajaran tersusun dalam rencana program pembelajaran mingguan (RPPM) dan perencanaan program pembelajaran harian (RPPH). Kemampuan guru merealisasikan perencanaan pembelajaran mencerminkan kompetensi yang dimilikinya sebagai guru professional. Kompetensi pedagogis terlihat bagaimana guru merencanakan metode pengajaran dan penerapannya yang sesuai dengan karakteristik anak. Keteladanan dan kedisiplinan dalam menyusun perencanaan merupakan pengembangan kompetensi kepribadiannya. Kompetensi sosial muncul saat guru membuat perencanaan pembelajaran yang adaptif, dalam arti bahwa bahan dan sumber ajar dekat dengan anak. Perencanaan pembelajaran sangat berpengaruh pada keberhasilan pencapaian sebuah kegiatan pembelajaran. Dalam arti sesuai dengan rencana yang dirancang, skenario pembelajaran yang ditetapkan dan indikator aspek perkembangan yang dipilih, sesuai dengan tema yang berlangsung.

E-Learning From Home adalah sebuah proses yang penting dilakukan oleh guru PAUD agar dapat membuat perkiraan tentang kegiatan yang akan dilakukan dalam pembelajaran dengan menyusun kurikulum, perencanaan dan penilaian yang dilakukan bekerjasama dengan orang tua melalui online. Hal itu juga berkaitan dengan komponen pembelajaran berdasarkan pada kompetensi anak didik. Di masa pandemic, guru PAUD berupaya memberikan pembelajaran pada anak didik secara jarak jauh atau disebut dengan E- Learning From Home. Anak didik melakukan pembelajaran sesuai dengan arahan dari gurunya di rumah dengan bantuan orang tua mereka, atau orang dewasa lainnya. Tentu saja akan terjadi distingsi karena berbagai faktor. Namun dapat diminimalisir dengan komunikasi guru dan orang tua yang lebih intens. Dibutuhkan kepiawaian guru dalam menyusun perencanaan pembelajaran yang disesuaikan dengan kondisi terkini, baik dalam hal metode pembelajaran, materi, model pembelajaran, bahkan indikator pencapaian yang ditargetkan. Dengan memanfaatkan fasilitas teknologi informasi terkini, strategi pembelajaran anak usia dini adalah menggunakan metode daring. Salah satu tujuan pengabdian ini guru PAUD harus meningkatkan kompetensi pedagogisnya, yakni meningkatkan kemampuan menyelenggarakan kegiatan pengembangan pembelajaran, dan memanfaatkan teknologi informasi dan komunikasi untuk meningkatkan kualitas pembelajaran yang mendidik, mulai membuka wawasan baru tentang perencanaan pembelajaran yang efektif dan efisien untuk menghadapi masa pandemic.

Hal itu bukanlah sesuatu yang mudah. Perlu diberikan pembekalan berupa pelatihan pada guru PAUD agar dapat mencapai tujuan dari pembelajaran, secara efektif dan efisien. Pemahaman tentang penyelenggaraan pelatihan akan mengarah pada bagaimana menyusun perencanaan pembelajaran program ini. Pelatihan merupakan serangkaian aktivitas dalam rangka memberikan pengetahuan dan keterampilan sesuai kebutuhan yang akan diterapkan pada saat itu. Menurut (Harding et al., 2018) usaha dalam bentuk peningkatan keterampilan dan pengetahuan, serta sikap dan perilaku yang disesuaikan dengan kebutuhan pekerjaan dan berkaitan dengan teknologi terbaru, adalah merupakan kegiatan pelatihan. Pelatihan pada guru PAUD tentang perencanaan pembelajaran di masa pandemic adalah sebuah urgensi yang harus segera dijalankan dengan tujuan agar memberikan pencerahan dan membuka wawasan baru bagaimana seharusnya mereka menjalankan peran sebagai guru. Pelatihan juga dimaksudkan untuk memperbaiki kemampuan yang sudah dimiliki guru dalam melaksanakan tanggung jawab profesi yang diampunya, memilih media yang tepat karena media sangat berpengaruh dan mempunyai kedudukan yang penting dalam mencapai tujuan pembelajaran efektif (Zaini \& Dewi, 2017) pembelajaran dapat tetap berlangsug dengan menyenangkan sesuai dengan kaidah pendidikan anak usia dini dan mengembalikan esensi pendidikan anak usia yang diawali dari pendidikan di rumah. 


\section{METODE PELAKSANAAN}

Metode pengabdian yang dilaksanakan menggunakan pendekatan partisipatif dengan berorientasi pada keikutsertaan guru dalam meningkatkan peran serta dalam pembelajaran ELearning secara langsung dalam berproses dan pelaksanaannya untuk anak. Adapun tahapantahapannya:

(1) Analisa situasi masyarakat.

Langkah awal pengabdian dengan survei lapangan, menentukan sasaran komunitas tertentu yaitu komunitas guru PAUD, karena pembelajaran dengan jarak jauh sehingga butuh cara yang tepat, efektif dan efisien untuk dapat diterapkan oleh guru pada anak, maka ditentukan bidang permasalahan pada pembelajaran E learning secara terbatas pada permasalahan perencanaan, pelaksanaan, dan evaluasi.

(2) Indentifikasi masalah.

Dilakukan untuk merumuskan masalah-masalah terupdate apa yang dapat dijadikan bahan pelatihan ,perancangan sistem, media pembelajaran, dan penyusunan materi pelatihan, kelengkapan peralatan dalam pengabdian E-learning from home yang dihadapi guru melalui kegiatan pengabdian.

(3) Menentukan tujuan kerja secara spesifik.

Tujuan diadakan pelatihan ini diharapkan suatu kondisi baru bagi guru PAUD agar dapat mengimplementasikan E-Learning PAUD from home dengan efektif dan efisien, dan mengerti berbagai media pembelajaran e learning.

(4) Rencana pemecahan masalah.

a. Mencari alternatif pemecahan masalah, b. Menentukan alternatif terbaik yang paling banyak memberikan kemudahan dan kebaikan buat guru PAUD dalam e-learning from home.

(5) Pendekatan sosial.

Subyek pengabdian adalah guru PAUD di lingkungan Kota Cimahi dengan beberapa orang yang dilibatkan secara langsung dengan ditumbuhkan kesadarannya untuk bersama-sama memecahkan bagaimana pembelajaran e learning from home yang tepat.

(6) Pelaksanaan pelatihan dan pendampingan.

Pelaksanaan pelatihan dan pendampingan dilaksanakan sesuai dengan perencanaan dilaksanakan di Cerah Eco School yang beralamat di Cipageran Asri C1 No. 6 Kota Cimahi, yang dilaksanakan pada bulan 19 November 2020 yang diikuti oleh guru-guru PAUD dilingkungan Kota Cimahi.

a. Sosialisai kegiatan dengan melakukan pendekatan pada HIMPAUDI, IGRA da IGTKI yang ada di lingkungan Kota Cimahi untuk meningkatkan kemampuan E -learning from Home guru PAUD. Pelatihan fokus dan mengarah pada kemampuan guru dalam E -learning From Home dengan media Whatshapp dan Google Classroom.

b. Pendampingan yang dilakukan bagaimana mennggunakan media yang tepat dan cara pengunaannya sebagai implementasi E-Learning From Home sampai dapat diterapkan oleh guru dalam pembelajaran jarak jauh selama masa pandemi Covid 19.

(7) Evaluasi kegiatan dan hasil.

Setelah pelaksanakan maka diadakan evaluasi untuk mengetahui sejauh mana tingkat keberhasilan pelatihan E Learning From Home dan pendampingan bagi guru PAUD, dari muklai awal, proses, hingga capaian agar dapat melangkah ke tahap berikutnya dan memperbaiki kekurangan dan menyempurnakan sesuai dengan harapan yang ingin dicapai. Juga mengevaluasi dampak bagi anak dan guru PAUD, mengamati perubahan sebagai 
bentuk pertanggung jawaban. Partisipasi dari HIMPAUDI, Igra dan IGTKI Kota Cimahi dalam program pengabdian masyarakat disambut dengan terbuka dan dapat diterima dengan baik.

\section{HASIL DAN PEMBAHASAN}

Sebagai langkah awal dalam proses pelatihan adalah menganalisa situasi masyarakat dan menentukan kebutuhan pelatihan yang dilakukan secara cermat. Peningkatan kualitas guru melalui pelatihan dalam perencaaan pembelajaran dalam situasi terkini tak dapat dilakukan secara tatap muka. Pada tanggal 11 maret 2020, disampaikan (McMichael et al., 2020), Hal ini dapat menghemat waktu, tenaga, dan biaya bagi panitia atau tim penyelenggara pelatihan. Waktu dan tempat pelatihan secara daring tentu saja sangat fleksibel, pelatihan dilksanakan pada tanggal 19 November 2020 dan melalui luring bertempat di Cerah Eco School dan zoom could meeting untuk kelanjutan pendampingan, namun menjadi bahan pertimbangan untuk memahami kondisi guru PAUD yang rata-rata adalah ibu rumah tangga dengan kesibukan domestik yang luar biasa. Pelatihan online atau Webinar dilaksanakan pada jam-jam kerja mereka pada umumnya yakni kisaran pukul 09.00 sampai pukul 12.00 wib. Berkaitan dengan tempat tentu saja merujuk pada aplikasi apa yang siap digunakan mudah dijangkau dan ramah kuota peserta yang mengaksesnya. pembelajaran creative learning adalah dengan melakukan inovasi pendampingan pembuatan media dan pembelajaran berbasis teknologi.(Mata \& Profesi, 2019). Agar program pelatihan berjalan baik dan tepat sasaran serta mencapai tujuan sesuai dengan yang diharapkan, perlu dilakukan proses analisis terlebih dahulu, sebagai berikut:

1. Analisis lingkungan, yakni perencanaan mengenai pengetahuan, keterampilan, perilaku yang diperlukan di masa sekarang, Rencana-rencana dituangkan dalam pernyataan jenis pelatihan yang dibutuhkan, tujuan akhir dari pelatihan, sumber daya dan dana untuk menunjang pelatihan tersebut, dan teknik pelatihan yang diminati. Wawancara secara mendalam dilakukan peneliti dengan pihak atau sumber data yang terlibat langsung dalam permasalahan agar data diperoleh sesuai dengan kondisi yang alami (Wahidmurni, 2017).

2. Analisis tugas, yang dimulai dengan meneliti uraian tugas dari seorang guru PAUD. Analisis tugas dapat menentukan tentang keterampilan, pengetahuan, sikap dan perilaku apa yang dapat diberikan dalam pelatihan yang akan diselenggarakan agar dapat secara efektif mengajar anak didiknya. Guru belajar lebih banyak lagi melalui pelatihan mengajar efektif, efisien dan menyenangkan melalui elektronik (Widiastuti et al., 2020).

3. Analisis individu, adalah upaya untuk menentukan siapa yang memerlukan pelatihan ini, dan bagaimana hasil yang akan didapat setelah pelatihan dilaksanakan. Pembelajaran elearning merupakan bentuk model pembelajaran dengan memanfaatkan teknologi, web dan internet. Selain platform dan situs edukasi yang telah tersedia, pemanfaatan siaran televisi edukasi juga diperlukan sebagai penunjang (Zhou et al., 2020). Berdasarkan hasil analisis lingkungan, didapatkan fakta bahwa dalam kondisi pandemic, guru harus mampu menyusun stratergi pembelajaran daring. Menurut (Sadikin \& Hamidah, 2020) penggunakan fasilitas internet yang mempunyai konektivitas, aksesibilitas, fleksibilitas dan dapat digunakan untuk interaksi pembelajaran secara maya dinamakan pembelajaran daring. Data-data yang diperoleh di lapangan dihimpun dan dianalisa secara induktif, lalu diuji kredibilitasnya sehingga menghasilkan data yang akurat, sehingga tujuan dari pengabdian ini dapat tercapai, yakni untuk mengetahui sejauh mana tingkat kebutuhan guru PAUD dalam mendapatkan pelatihan perencanaan pembelajaran dalam masa pandemic COVID 19. Pengabdi memaparkan hasil dari pengumpulan data secara naratif . Penelitian ini juga diharapkan dapat membuka wawasan dan memberikan solusi bagi guru PAUD dalam melaksanakan PAUD From Home/ E Learning From Home.

Berdasarkan hasil identifikasi masalah maka, jenis pelatihan yang dibutuhkan adalah bagaimana membuat media pembelajaran secara daring, bagaimana meningkatkan pengetahuan guru, membuka wawasan baru. Pelatihan bagi guru PAUD dalam membuat perencanaan pembelajaran daring sangat dibutuhkan karena: 
1. Guru tidak siap menghadapi kondisi penyelenggraan KBM tanpa tatap muka.

2. Guru harus dibekali tujuan yang utama dari E-LearningFrom Home

3. Guru harus memahami kondisi psikologis anak didik

4. Guru menjalin kerjasama dengan orang tua siswa terkait kegiatan Paud From Home

5. Membuka wawasan guru untuk terampil menggunakan media alat komunikasi sebagai media pembelajaran E-Learning From Home

Adapun narasumber pelatihan berasal dari pihak yang berkompeten dalam bidangnya. Pihak penyelenggara bisa dilakukan oleh Dinas Pendidikan Kota, institusi pendidikan dalam hal ini IKIP Siliwangi, organisasi mitra ( HIMPAUDI, IGRA, dan IGTKI) yang berkolaborasi dengan pihak swasta, atau sebuah komunitas yang berkecimpungan dalam bidang pendidikan anak usai dini. Berdasarkan observasi peneliti mendapatkan data yang menguatkan bahwa pelaksanaan pelatihan perencanaan pembelajaran jelas sekali urgensinya. Melalui metode penelitian dokumentasi, peneliti menmukan perbedaan yang signifikan antara sebelum dan setelah pelatihan dilaksanakan. Data-data yang diperoleh di lapangan dihimpun dan dianalisa secara induktif, lalu diuji kredibilitasnya sehingga menghasilkan data yang akurat, sehingga tujuan dari penelitian ini dapat tercapai, yakni untuk mengetahui sejauh mana tingkat kebutuhan guru PAUD dalam mendapatkan pelatihan perencanaan pembelajaran dalam masa pandemic COVID 19. Peneliti memaparkan hasil dari pengumpulan data secara naratif . Penelitian ini juga diharapkan dapat membuka wawasan dan memberikan solusi bagi guru PAUD dalam melaksanakan PAUD From Home.

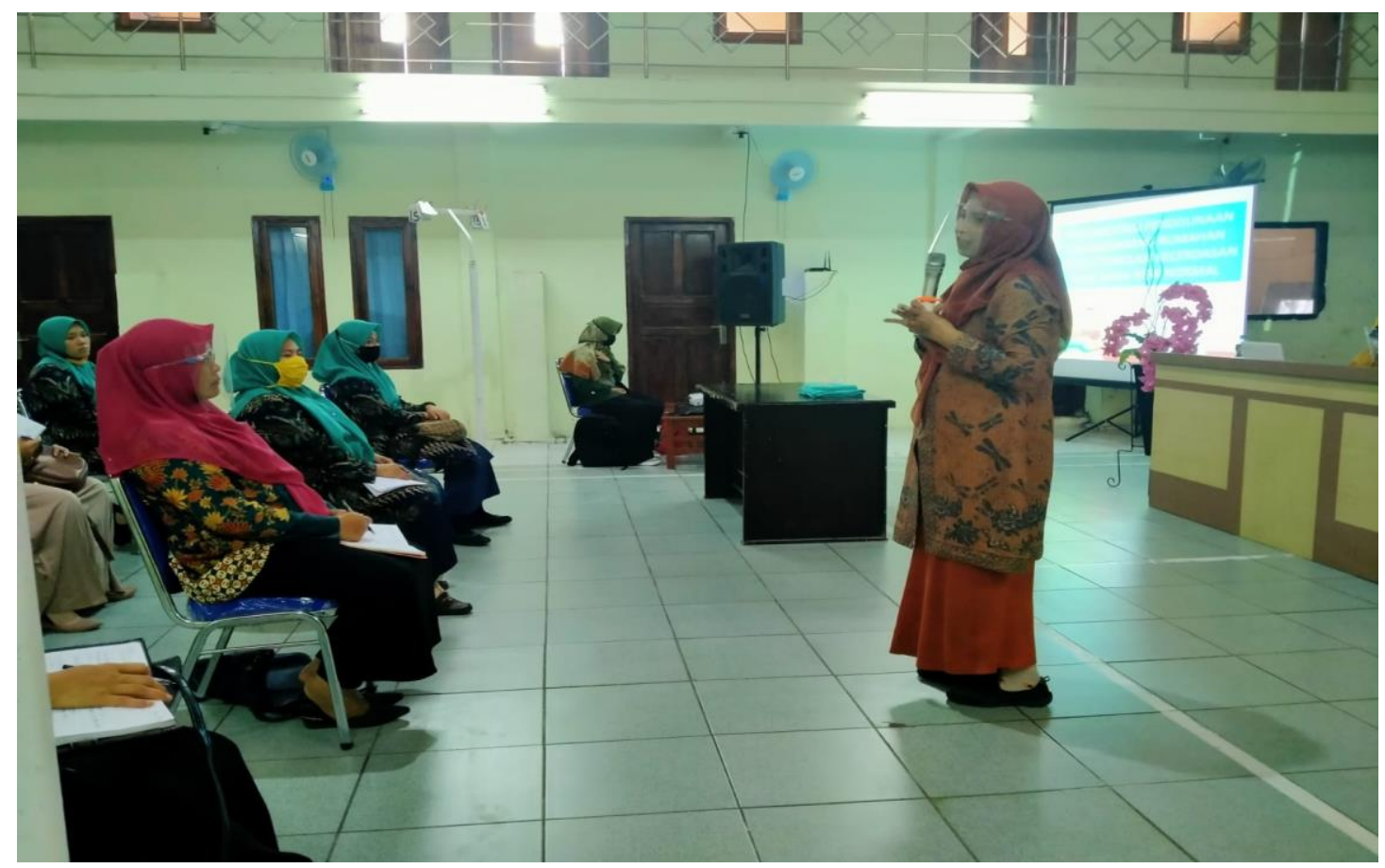

Gambar 1. Pelaksanaan Pelatihan E-Learning untuk Guru

Dilihat dari tugas, Maka tujuan dari pengabdian ini diharapkan guru PAUD sebagai aktor utama dalam mendidik, mengajar membimbing, melatih dan mengevaluasi anak usia dini mempunyai tugas dan kewajiban membuat perencanaan pembelajaran, dengan tetap melakukan proses pembimbingan dan penilaian. Guru PAUD melakukan perencanaan pembelajaran dengan menyusun rencana pembelajaran harian yang selanjutnya diberikan kepada orang tua dengan lembar kegiatan dan diberikan melalui soft file yang dikirim di media social(Hewi \& Asnawati, 2020). Pengajaran perlu interaksi antar komponen pembelajaran agar 
terwujud pembelajaran yang efisien (Pane \& Darwis Dasopang, 2017)Untuk itu dibutuhkan pelatihan bagaimana merancang perencanaan pembelajaran yang sekaligus dapat membimbing dan memberikan evalusi secara daring. Materi pelatihan yang diminati guru PAUD antara lain:

- Menyusun RPP E-Learning From Home

- Berkarya dari rumah (loosepart)

- Psikologi anak dan orang tua

- Teknik mengevaluasi

- Berbagi kuota gratis

Rencana pemecahan masalahnya berdasarkan analisis individu, didapatkan data bahwa guru PAUD yang mengikuti pelatihan ini berkualifikasi pendidikan minimal Strata 1 atau mereka yang memahami penggunaan internet dan media teknologi komunikasi lainnya, Kebijakan regulatif bersifat mengatur dan membatasi dalam kontek kebijakan e-learning yang mengatur kegiatan pembelajaran dilaksanakan dari rumah dengan e-learning (Nurkolis \& Muhdi, 2020), sehingga hasil dari pelatihan dapat diterapkan langsung dalam kegiatan pembelajaran. Kepala sekolah sebagai pemangku kebijakan tentu saja harus terlibat dalam pelatihan ini karena tugas beliau dalam membuat perencanaan pembelajaran bersama tim guru, serta melibatkan orang tua dalam mengoptimalkan hasil pembelajaran (Gunadi, 2019). Adapun media yang biasa digunakan untuk pelatihan secara online (webinar) adalah:

- WAG ( WhatsappGroup)

- Zoom meeting, Jitsy atau Google meeting

- Telegram grup

- Instagram TV

- Youtube

- Google classroom

- Facebook Streaming

Berdasarkan hasil wawancara, media pelatihan yang diminati guru adalah sebagai berikut:

1. Media atau aplikasi yang hemat kuota

2. Aplikasi yang mudah digunakan

3. Dapat diakses menggunakan HP atau Laptop

4. Tidak menggunakan banyak memori

Teknis pelaksanaan yang sering diikuti banyak peserta adalah webinar yang tidak berbayar, bersertifikat (E-sertifikat) dan mendapatkan materi yang dibagikan secara online. Media webinar yang banyak diikuti adalah pelatihan yang menggunakan aplikasi Zoom meeting, Google meeting atau Webex, sebagai media. Pertimbangannya adalah karena peserta pelatihan dapat melakukan tatap muka secara online, sehingga materi yang disampaikan lebih mudah diingat dan dipahami. Penggunaan media WAG (Whatshapp Group) menempati urutan kedua diminati karena lebih pada kurang menyukai membaca postingan pemateri, dan tidak ada interaksi antara pemateri dan peserta. Media Streaming Youtube cukup digemari karena guru dapat menggunakan fasilitas kuota gratis Youtube dan tidak perlu hadir di 'ruangan' meeting secara visual, tapi dapat menyaksikan wajah pemateri dan materi yang ditayang secara online. Peserta pelatihan adalah guru PAUD Kota Cimahi. Mereka sangat antusias mengikuti pelatihan untuk diterapkan dalam proses pembelajaran di lembaganya masing-masing. Guru PAUD memilih pelatihan daring dengan pertimbangan: 


\section{Bersertifikat}

2. Ada perhitungan Jampel ( Jam Pelajaran)

3. Skala seminar nasional atau internasional

4. Tidak berbayar/ Gratis

5. Pemateri yang terkenal, menarik perhatian dan menguasai di bidangnya.

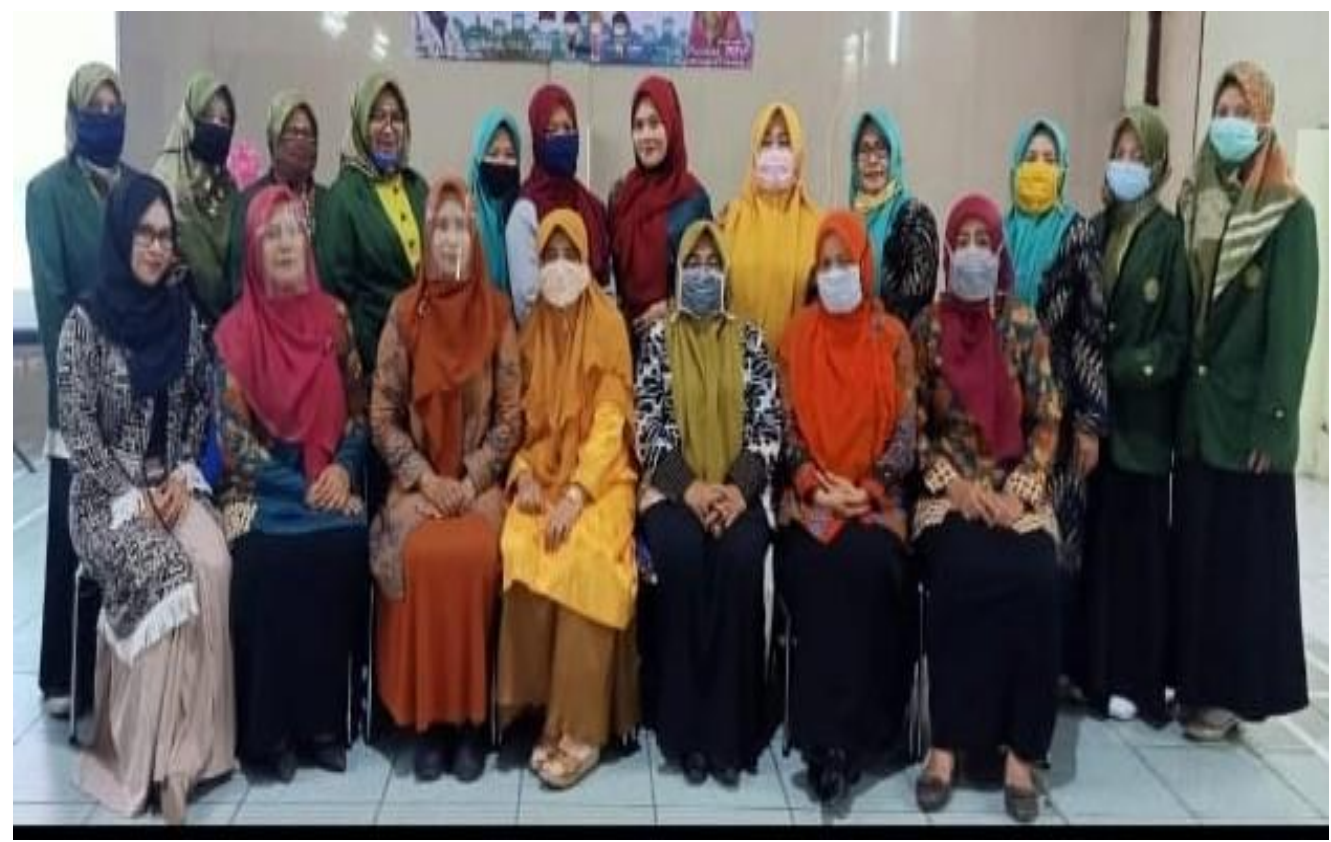

Gambar 2. Sebagian peserta pelatihan E-Learning untukguru

Dari hasil, pelatihan yang diselenggarakan untuk guru PAUD dalam E- Learning From Home di masa pandemic menunjukkan hasil yang sangat baik. Hal itu terlihat dari indikator sebegai berikut:

- Jumlah peserta pelatihan yang sesuai harapan karena apresiasi huru dan keingin tahunan guru PAUD yang tinggi untuk lebih maju lagi

- KTSP yang telah disusun masing-masing lembaga disesuaikan dengan kondisi pandemi, tema disesuaikan pula dengan sekolah masing-masing.

- Jumlah anak didik yang terlayani semakin bertambah, walaupun sedang pandemi akan tetapi karena kebutuhan anak akan masukpada jenjang pendidikan berikutnya.

- Guru yang semakin cerdas, otomatis guru harus kreatif, inovatif, lebih banyak belajarn utuk dapat mengikuti perkembangan, situasi dan kondisi menggunakan E-Learning.

- Aplikasi di lapangan, yang semakin beragam, respon orang tua peserta didik yang positif dan postingan di media sosial yang turut meramaikan dan mengguatkan berbagai pihak.

- Orang tua / wali yang setadinya kurang komunikasi dengan guru menjadi terpicu untuk terus melakukan komunikasi dalam mendampingi kegiatan belajar anak dan menanyakan kendala-kendala yang kadang terjadi di rumah.

Sedangkan hasil observasi terhadap para guru PAUD yang telah mengikuti pelatihan didapatkan data sebagai berikut: 
Table 1. Pencapaian hasil pelatihan

\section{Setelah Pelatihan}

Kepala Sekolah Menyusun perencanaan pembelajaran seperti biasa pada umumnya, berupaya menerapkan apa adanya.

Mengejar target pencapaian sesuai dengan indikator dan lebih pada penugasan yang struktural.

\section{Sebelum Pelatihan}

Menyusun

perencanaan pembelajaran sesuai kebutuhan siswa, dan kondisi orang tua.

Menentukan target pencapaian yang fleksible, dan lebih mengarah pada peningkatan life skill.

\section{Guru}

\author{
Membagikan Lembar Kerja Siswa untuk \\ dikerjakan di rumah.
}

Membagikan video pembelajaran dengan sentuhan secara visual (Senyuman dan sapaan)

Memberikan penugasan seperti di sekolah yang dikerjakan di rumah

Memberikan rewad berupa pujian dan memndorong anak untuk tetap semangat mengerjakan kegiatan di rumah.

Pembelajaran lebih dominan dilakukan di sekolah didampingi guru
Menekankan pada pembelajaran kebersamaan dengan keluarga.

Evaluasi dilakukan setelah dilaksanakan pelatihan untuk guru dengan melakukan pendampingan banik secara luring ataupun daring, karena mengingat pandemi masih sedang berlangsung maka pendampingan lebih sering dilakukan dengan online baik menggunakan Whatsapp Group ataupun melalui Zoom Could Meeting, pada awalnya guru merasa kesulitan untuk menguasai bagaimana membuat media pembelajaran untuk anak menggunakan youtube akan tetapi setelah dilakukan pendampingan maka lambat laun guru mulai dapat adaptasi dan ada keinginan untuk belajar. Guru merasa dipacu dan harus menyesuaikan dengan kebutuhan zaman serta berinovasi menggunakan pembelajaran E-Learning From Home, sehingga pembelajaran menjadi hal yang menyenangkan untuk anak dan mudah diikuti serta orang tua dapat menyesuaikan dengan waktu serta kemampuannya.

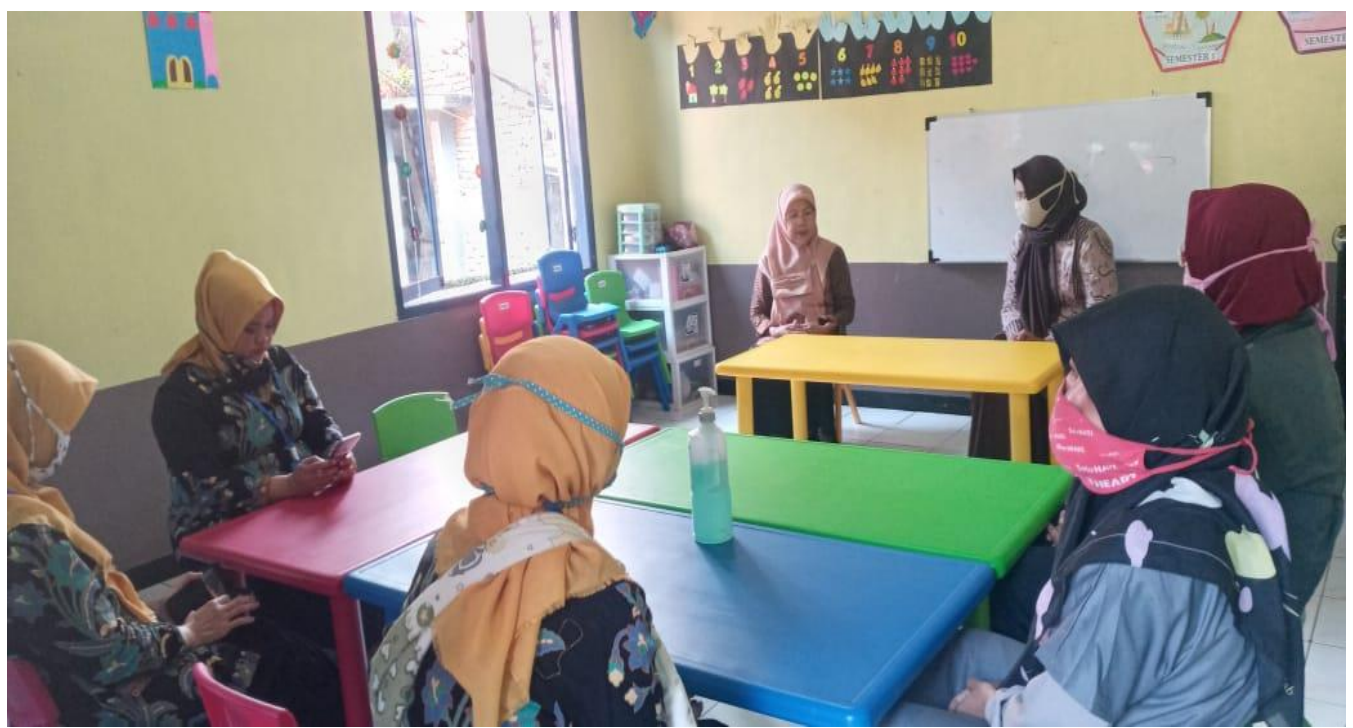

Gambar 3. Pendampingan setelah pelaksanaan Pelatihan E-Learning 


\section{SIMPULAN DAN TINDAK LANJUT}

Berdasarkan hasil kegiatan pengabdian pada masyarakat yang berupa pelatihan E Learning From Home bagi guru Pendidikan Anak Usis Dini pada masa Pandemic Covid 19 dapat disimpulkan sebagai berikut:

1. Pelatihan E-Learning From Home dapat dilaksanakan dengan baik sesuai dengan perencanaan dan lancar tanpa ada hambatan yang berarti. Dengan menggunakan media pelatihan secara tatap muka dan pendampingan, para guru mendapatkan wawasan dan pencerahan bagaimana seharusnya merancang perencanaan pembelajaran yang sesuai dengan situasi kekinian yag mengharuskan pembelajaran dari rumah

2. Kegiatan pelatihan ini memberikan pengetahuan kepada guru PAUD tentang bagaimana ELearning From Home dan kemampuan guru meningkat setelah diadakan pelatihan. Penerapan hasil pelatihan mulai terlihat dari semakin banyaknya guru yang membuat media pembelajaran di media sosial dan orang tua yang mulai merasa nyaman dengan program kegiatan Pembelajaran From Home. Adapun media pelatihan yang diminati guru adalah sebagai berikut, media atau aplikasi yang hemat kuota, aplikasi yang tidak membingungkan mudah digunakan, dapat diakses menggunakan HP atau Laptop dan tidak menggunakan banyak memori.

3. Guru PAUD mengalami beberapa kendala dalam E-Learning From Home, diantaranya kemampuan personal dalam kecakapan menguasai IT, terbatasnya perangkat, terbatasnya quota dan terbatasnya waktu serta kesibukan lainnya.

Guru PAUD setelah pelatihan mampu memperbaiki kemampuan IT dan dapat mengimplementasikan E Learning From Home untuk pembelajaran anak sehingga hasil yag ditargetkan/diharapkan baik oleh guru ataupun orang tua dapat tercapai. Pelatihan E Learning From Home dapat menunjang guru PAUD untukmengatasi masalah yang timbul pada saat pandemic Covid 19. Diharapkan ada kelanjutan dari pelatihan ini berupa pelatihan bagaimana membuat animasi sederhana untuk pembelajaran anak usia dini agar menarik dan tidak membosankan serta gambar yang bergerak diharapkan lebih menarik, sebagai langkah berikutnya baik berupa pelatihan online ataupun dilaksanakan tatap muka dengan mengindahkan protokol kesehatan.

\section{DAFTAR PUSTAKA}

Armiyati, W. D. E., Mappapoleonro, A. M., \& Iriansyah, H. S. (2019). Peningkatan Kemampuan Mengenal Warna dengan Metode Eksperimen. 1-8.

Ashcroft, P., Lehtinen, S., Angst, D. C., Low, N., \& Bonhoeffer, S. (2020). Quantifying the impact of quarantine duration on COVID-19 transmission. MedRxiv, 2, 2020.09.24.20201061. http://medrxiv.org/content/early/2020/10/05/2020.09.24.20201061.abstract

Gunadi, D. I. P. (2019). Peran Orang Tua dalam Optimalisasi Tumbuh Kembang Anak untuk Membangun Karakter Jujur. 34-47. https://doi.org/10.31227/osf.io/zdt3g

Harding, D., Kadiyono, A. L., Hidayat, Y \& Yuniarti, N. (2018). Human resource training and development asan answer toaec challenge. Jurnal Psikologi Sains Dan Profesi, 2(2), 185-192

Hewi, L., \& Asnawati, L. (2020). Strategi Pendidik Anak Usia Dini Era Covid-19 dalam Menumbuhkan Kemampuan Berfikir Logis. Jurnal Obsesi : Jurnal Pendidikan Anak Usia Dini, 5(1). https://doi.org/10.31004/obsesi.v5i1.530

Mata, D., \& Profesi, K. (2019). 1 , 2 , \& 3 1. 14(2), 32-41.

McMichael, T. M., Currie, D. W., Clark, S., Pogosjans, S., Kay, M., Schwartz, N. G., Lewis, J., Baer, A., Kawakami, V., Lukoff, M. D., Ferro, J., Brostrom-Smith, C., Rea, T. D., Sayre, M. R., Riedo, F. X., Russell, D., Hiatt, B., Montgomery, P., Rao, A. K., ... Duchin, J. S. (2020). Epidemiology of 
Covid-19 in a Long-Term Care Facility in King County, Washington. New England Journal of Medicine, 382(21), 2005-2011. https://doi.org/10.1056/nejmoa2005412

Nurkolis, N., \& Muhdi, M. (2020). Keefektivan Kebijakan E-Learning berbasis Sosial Media pada PAUD di Masa Pandemi Covid-19. Jurnal Obsesi : Jurnal Pendidikan Anak Usia Dini, 5(1), 212. https://doi.org/10.31004/obsesi.v5i1.535

Pane, A., \& Darwis Dasopang, M. (2017). Belajar Dan Pembelajaran. FITRAH:Jurnal Kajian IlmuIlmu Keislaman, 3(2), 333. https://doi.org/10.24952/fitrah.v3i2.945

Sadikin, A., \& Hamidah, A. (2020). Pembelajaran Daring di Tengah Wabah Covid-19. Biodik, 6(2), 109-119. https://doi.org/10.22437/bio.v6i2.9759

Sufiati, V., \& Afifah, S. N. (2019). Peran perencanaan pembelajaran untuk performance mengajar guru pendidikan anak usia dini. Jurnal Pendidikan Anak, 8(1), 48-53. https://doi.org/10.21831/jpa.v8i1.26609

Wahidmurni. (2017). Pemaparan Metode Penelitian Kuantitatif. 1-9.

Widiastuti, Y. K. W., Rasmani, U. E. E., \& Wahyuningsih, S. (2020). Mengkaji Penerapan ELearning pada Anak Usia Dini. Jurnal Obsesi : Jurnal Pendidikan Anak Usia Dini, 5(2), 1240 1247. https://doi.org/10.31004/obsesi.v5i2.752

Zaini, H., \& Dewi, K. (2017). Pentingnya Media Pembelajaran Untuk Anak Usia Dini. Raudhatul Athfal: Jurnal Pendidikan Islam Anak Usia Dini, 1(1), 81-96. https://doi.org/10.19109/ra.v1i1.1489 